\title{
Methods for improving oxygenation in infants mechanically ventilated for severe hyaline membrane disease
}

\author{
S. HERMAN and E. O. R. REYNOLDS \\ From the Department of Paediatrics, University College Hospital, London
}

\begin{abstract}
Herman, S., and Reynolds, E. O. R. (1973). Archives of Disease in Childhood, 48, 612. Methods for improving oxygenation in infants mechanically ventilated for severe hyaline membrane disease. The effect on arterial blood gas tensions, aortic blood pressure, and intra-oesophageal pressure of altering inspiration: expiration ratio and pressure during expiration was investigated in 9 infants being treated by mechanical ventilation for very severe hyaline membrane disease. The results showed that the use of a long inspiratory phase and a positive expiratory pressure acted synergistically to reduce alveolar-arterial oxygen difference and estimated right-to-left shunt: this reduction was proportional to mean airway pressure. The usefulness of a positive expiratory pressure in raising arterial oxygen tension was limited by its effect in causing alveolar hypoventilation. No adverse effects on the circulation due to the application of high mean airway pressures were detected.
\end{abstract}

The principal abnormality in hyaline membrane disease (respiratory distress syndrome of the newborn) is deficiency of pulmonary surfactant which causes alveoli to collapse during expiration (Avery and Mead, 1959). Recent work by Gregory et al. (1971) and others (Chernick and Vidyasagar, 1972) has shown that arterial oxygenation can be substantially improved when the alveoli are held open by allowing the infant to breathe spontaneously against a continuous positive transpulmonary pressure. Nevertheless, the most severely affected infants still need mechanical ventilation (Swyer et al., 1973).

Many infants ventilated for hyaline membrane disease have in the past died from bronchopulmonary dysplasia (pulmonary fibroplasia) which is probably caused by at least two factors: mechanical trauma to the lung from the use of high peak airway pressures and oxygen toxicity (Hawker, Reynolds, and Taghizadeh, 1967; Northway, Rosan, and Porter, 1967; Banerjee, Girling, and Wigglesworth, 1972). We have therefore tried to find means for ventilating the infants at comparatively low peak airway pressures and at oxygen concentrations reduced as far as possible below $100 \%$.

Received 6 December 1972.
It was shown in a previous study (Reynolds, 1971) that when using a constant pressure generator (Mushin et al., 1969) the best arterial oxygen tension was obtained with a slow respiratory frequency $(30 / \mathrm{min})$, and that arterial oxygen tension could be improved without increasing peak airway pressure by using a very long inspiratory phase (an inspiration: expiration ratio of $2: 1$ or more). This manoeuvre had no effect on arterial carbon dioxide tension or aortic blood pressure.

In 1970, Llewellyn and Swyer presented preliminary evidence that the use of a positive pressure in expiration was also effective in raising the arterial oxygen tension of infants mechanically ventilated for hyaline membrane disease. The purpose of the present investigation was to find out which of the two manoeuvres (a long inspiration or a positive expiratory pressure) was the more effective in improving arterial oxygen tension, and to see if the two techniques were additive in their effects.

\section{Infants studied}

The investigation was performed on 9 infants with the clinical and radiological features of severe hyaline membrane disease who required mechanical ventilation. Their mean birthweight was $1600 \mathrm{~g}$ (range 870-2155 g) and their mean gestational age 31 weeks (27-33 weeks): 
5 of the infants were boys and 4 were girls. The indications for ventilation were apnoea from birth (1 infant), an arterial oxygen tension $\left(\mathrm{PaO}_{2}\right)$ below 35 $\mathrm{mmHg}$ while breathing an inspired oxygen concentration greater than $95 \%$ for more than 15 minutes ( 2 infants), or 'incipient collapse', in other words, a clinical deterioration accompanied by peripheral vasoconstriction, a fall in respiratory frequency with interposed gasps, and a fall in heart rate (6 infants). The mean age at which mechanical ventilation was started was 11 hours (birth46 hours). Oroendotracheal tubes (Warne 12F) were used and the ventilator was the Bennett PR2. The technique of management of the infants while undergoing mechanical ventilation has been described elsewhere (Reynolds, 1970, 1971, 1973). The mean age at which the study was carried out was 24 hours ( $8-58$ hours). 4 infants were subsequently weaned from the ventilator using the technique of continuous positive airway pressure (Gregory et al., 1971). Attempts to wean the remaining 5 infants did not succeed and they died. At necropsy the pathological changes of hyaline membrane disease were always found : intraventricular haemorrhages were present in 3 infants.

\section{Methods}

Variations in ventilator settings. The ventilator was set as a constant pressure generator (Mushin et al., 1969) delivering a pressure wave approximating to a square wave, as illustrated previously (Reynolds, 1971). The ventilating gas was fully humidified at body temperature, with an oxygen concentration constant for each infant and in the range 83 to $100 \%$ (mean 95\%). All variables of ventilation other than inspiration : expiration ratio and expiratory pressure were kept constant; peak airway pressure was $25 \mathrm{~cm} \mathrm{H}_{2} \mathrm{O}$, and respiratory frequency $30 / \mathrm{min}$. Alterations in expiratory pressure were made by collecting expired gas in the spirometer attachment of the ventilator and leading it to a variable resistance constructed from a $500 \mathrm{ml}$ anaesthetic bag with a screw clamp on the outlet, together with a water column to act as a safety valve, as described for continuous positive airway pressure breathing by Gregory et al. (1971).

Once the infant's condition on the ventilator had been stable for at least 2 hours, a series of random alterations in inspiration : expiration ratio and expiratory pressure (determined from a system of sealed envelopes) were undertaken and the effects on $\mathrm{PaO}_{2}, \mathrm{PaCO}_{2}$, arterial $\mathrm{pH}$ $(p \mathrm{Ha})$, base excess (BE), and aortic blood pressure were measured. Three expiratory pressures, 0,5 , and $10 \mathrm{~cm}$ $\mathrm{H}_{2} \mathrm{O}$ were investigated, each at two inspiration : expiration ratios, $1: 2$ and $2: 1$, giving a total of six alterations in pressure wave form (Fig. 1). After each change in ventilator settings, the lungs were held inflated at a pressure of $25 \mathrm{~cm} \mathrm{H}_{2} \mathrm{O}$ for 5 seconds, and 15 minutes were then allowed to elapse before samples of arterial blood for analysis and readings of arterial blood pressure were taken.

The infants usually made no attempts to breathe against the ventilator. No steps were taken to control any such attempts as did occur.

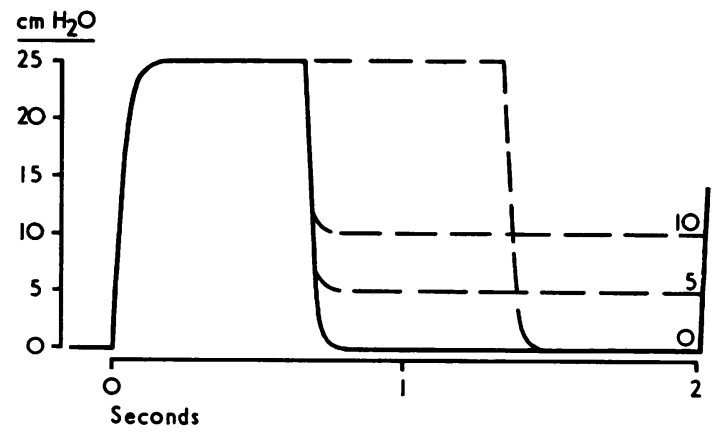

FIG. 1.-Pressure wave forms investigated. The two inspiration:expiration ratios $(1: 2$ and $2: 1)$ and three expiratory pressures $\left(0,5\right.$, and $\left.10 \mathrm{~cm} \mathrm{H}_{2} \mathrm{O}\right)$ are illustrated.

Arterial blood gas tensions, arterial pH (pHa), and base excess. In 7 infants a 5F Argyle catheter was introduced via the umbilical artery into the descending aorta and was verified radiologically to be at the level of the 2nd or 3rd lumbar vertebra. After flushing the dead space, 1.0 to $1.5 \mathrm{ml}$ blood samples were taken into heparinized syringes. In the 2 remaining infants similar samples were obtained by puncture of the right radial or brachial artery.

The samples were immediately analysed for $\mathbf{P a O}_{2}$, $\mathrm{PaCO}_{2}, \mathrm{pHa}$, and base excess using Radiometer equipment as described previously (Adamson et al., 1969). The inspired oxygen concentration was repeatedly checked with a Beckman D2 or Tekmar oxygen analyser.

Alveolar-arterial oxygen difference (A-aDo $)_{2}$. 'Ideal' alveolar oxygen tension was derived from the alveolar air equation (Riley and Cournand, 1949) assuming a respiratory exchange ratio of $0 \cdot 8 . \mathrm{A}_{-}-\mathrm{aDo}_{2}$ was then obtained by difference.

Arterial blood pressure, airway pressure, and intra-oesophageal pressure. Arterial blood pressure was measured by attaching the arterial catheter directly to a Sanborn 267BC strain-gauge transducer and recording equipment. Airway pressure was measured by inserting a wide-bore needle into the ventilator tubing just proximal to the endotracheal tube and connecting it by means of a stiff catheter to a Sanborn 270 transducer. Intra-oesophageal pressure was measured in latex balloons (Senterre and Geubelle, 1970) passed into the midoesophagus of two infants. After the introduction of 0.3 to $0.5 \mathrm{ml}$ air, the pressures developed were recorded in a similar manner.

Statistical methods. Statistical analysis was carried out with the Student's ' $t$ ' test for paired data.

\section{Results}

The results are set out in the Table and in Fig. 2. Because values obtained from samples taken from the arteries of the right arm (preductal) were similar 


\section{TABLE}

Effect of altering inspiration:expiration ratio and expiratory pressure on arterial $\mathrm{pH}(\mathrm{pHa})$, base excess $(B E)$, and mean aortic blood pressure (MBP)

\begin{tabular}{|c|c|c|c|c|c|c|}
\hline \multirow{2}{*}{$\frac{\text { Inspiration : expiration ratio }}{\text { Expiratory pressure }\left(\mathrm{cm} \mathrm{H}_{2} \mathrm{O}\right)}$} & \multicolumn{3}{|c|}{$1: 2$} & \multicolumn{3}{|c|}{$2: 1$} \\
\hline & 0 & 5 & 10 & 0 & 5 & 10 \\
\hline $\begin{array}{l}\text { pHa } \\
\text { BE (mEq/l.) } \\
\text { MBP (mmHg) }\end{array}$ & $\begin{array}{c}7 \cdot 37 \\
\pm 0 \cdot 02 \\
3 \cdot 4 \\
\pm 1 \cdot 5 \\
35 \cdot 3 \\
\pm 2 \cdot 0\end{array}$ & $\begin{array}{r}7 \cdot 31 \\
\pm 0 \cdot 02 \\
2 \cdot 5 \\
\pm 1 \cdot 4 \\
36 \cdot 9 \\
\pm 1 \cdot 6\end{array}$ & $\begin{array}{c}7 \cdot 25 \\
\pm 0 \cdot 02 \\
2 \cdot 2 \\
\pm 1 \cdot 6 \\
37 \cdot 3 \\
\pm 1 \cdot 8\end{array}$ & $\begin{array}{r}7 \cdot 36 \\
\pm 0 \cdot 01 \\
3 \cdot 3 \\
\pm 1 \cdot 3 \\
36 \cdot 3 \\
\pm 1 \cdot 9\end{array}$ & $\begin{array}{c}7 \cdot 32 \\
\pm 0 \cdot 03 \\
3 \cdot 1 \\
\pm 1 \cdot 3 \\
37 \cdot 4 \\
\pm 2 \cdot 4\end{array}$ & $\begin{array}{r}7 \cdot 25 \\
\pm 0.03 \\
1.7 \\
\pm 1.5 \\
38.0 \\
\pm 1.9\end{array}$ \\
\hline
\end{tabular}

Note: Mean values \pm 1 SEM are shown.

to those found in aortic samples (postductal), they have been analysed together.

$\mathbf{P a O}_{2}, \mathbf{P a c o}_{2}$, and $\mathbf{A}-\mathbf{a D o}_{2}$

Effect of altering inspiration:expiration (I:E) ratio. At each expiratory pressure (EP) $\mathrm{PaO}_{2}$ was higher at an $I: E$ ratio of $2: 1$ than at a ratio of $1: 2$ (EP $0 \mathrm{~cm} \mathrm{H}_{2} \mathrm{O}, \mathrm{P}<0.0025$; EP $5 \mathrm{~cm} \mathrm{H}_{2} \mathrm{O}, \mathrm{P}<0.0025$; EP $10 \mathrm{~cm} \mathrm{H}_{2} \mathrm{O}, \mathrm{P}<0.025$ for the mean difference between paired readings). $\mathrm{PaCO}_{2}$ did not change. $\mathrm{A}-\mathrm{aDO} \mathrm{O}_{2}$ was always lower at an $\mathrm{I}: \mathrm{E}$ ratio of $2: 1$ (EP $0 \mathrm{~cm} \mathrm{H} \mathrm{H}_{2} \mathrm{O}, \mathrm{P}<0.005$; $\mathrm{EP} 5 \mathrm{~cm} \mathrm{H} \mathrm{H}_{2} \mathrm{O}$, $\mathrm{P}<0.0025$; EP $\left.10 \mathrm{~cm} \mathrm{H}_{2} \mathrm{O}, \mathrm{P}<0.025\right)$.

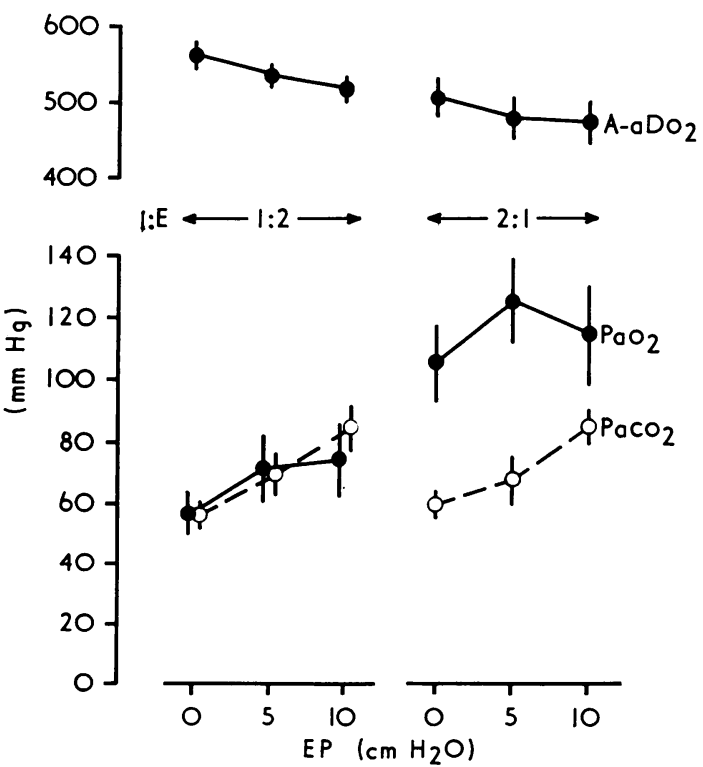

FIG. 2.-Effect of altering inspiration:expiration (I:E) ratio and expiratory pressure (EP) on alveolar-arterial oxygen difference $\left(A-a \mathrm{Do}_{2}\right)$, arterial oxygen tension $\left(\mathrm{PaO}_{2}\right)$, and arterial carbon dioxide tension $\left(\mathrm{PaCO}_{2}\right)$. Mean values \pm 1 SEM are shown.
Effect of altering expiratory pressure $(E P)$. At both I:E ratios, $\mathrm{PaO}_{2}$ was higher with an $\mathrm{EP}$ of $5 \mathrm{~cm} \mathrm{H} \mathrm{H}_{2} \mathrm{O}$ than at $0 \mathrm{~cm} \mathrm{H}_{2} \mathrm{O}(\mathrm{P}<0.05)$. No further changes in $\mathrm{PaO}_{2}$ occurred at an EP of $10 \mathrm{~cm} \mathrm{H} \mathrm{H}_{2} \mathrm{O}$. With an I:E ratio of $1: 2, \mathrm{PaCO}_{2}$ was higher with an EP of 5 $\mathrm{cm} \mathrm{H}_{2} \mathrm{O}$ than at $0 \mathrm{~cm} \mathrm{H}_{2} \mathrm{O}$ : at both $\mathrm{I}: \mathrm{E}$ ratios $\mathrm{PaCO}_{2}$ was higher with an EP of $10 \mathrm{~cm} \mathrm{H}_{2} \mathrm{O}$ than at 5 $\mathrm{cm} \mathrm{H}_{2} \mathrm{O}$ (I:E 1:2, $\mathrm{P}<0.05$; I:E 2:1, $\left.\mathrm{P}<0.0025\right)$. With an $\mathrm{I}: \mathrm{E}$ ratio of $1: 2, \mathrm{~A}-\mathrm{aDo}_{2}$ fell as EP increased (EP $0 \mathrm{~cm} \mathrm{H}_{2} \mathrm{O}$ vs $5 \mathrm{~cm} \mathrm{H}_{2} \mathrm{O}, \mathrm{P}<0.0025$; EP 5 $\mathrm{cm}_{2} \mathrm{O}$ vs $\left.10 \mathrm{~cm} \mathrm{H}_{2} \mathrm{O}, \mathrm{P}<0.005\right)$ : with an $\mathrm{I}$ : E ratio of $2: 1, \mathrm{~A}-\mathrm{aDo}_{2}$ was less at an $\mathrm{EP}$ of $5 \mathrm{~cm} \mathrm{H}_{2} \mathrm{O}$ than at $0 \mathrm{~cm} \mathrm{H}_{2} \mathrm{O}(\mathrm{P}<0.025)$.

pHa, base excess, and mean aortic blood pressure. Changes in $\mathrm{pHa}$ were due to alterations in $\mathrm{PaCO}_{2} ;$ base excess was unaffected. Mean aortic blood pressure did not alter during the study.

Intra-oesophageal pressure. Intra-oesophageal pressure swings were always very small in the two infants studied, with recorded pressures varying between -1 and $+3 \mathrm{~cm} \mathrm{H}_{2} \mathrm{O}$ during cycling in one infant, and between -2 and $+2 \mathrm{~cm} \mathrm{H}_{2} \mathrm{O}$ in the other.

Correlation between mean airway pressure and $\mathbf{A}-\mathbf{a D o}_{2}$. An extremely close correlation was found between mean airway pressure (MAP) and $\mathrm{A}-\mathrm{aDO}_{2}$ (Fig. 3). The linear relation between these two variables is described by the equation

$$
\mathrm{A}-\mathrm{aDo}_{2}=-7.45 \mathrm{MAP}+625 \cdot 45 \quad(\mathrm{r}=0.99 \text {, }
$$$$
\mathrm{P}<0 \cdot 0005) \text {. }
$$

\section{Discussion}

Gas exchange. This study confirms that the use of a long inspiratory phase raises $\mathrm{PaO}_{2}$ without changing $\mathrm{PaCO}_{2}$ in infants mechanically ventilated for hyaline membrane disease (Reynolds, 1971). The addition of a positive pressure in expiration of $5 \mathrm{~cm} \mathrm{H}_{2} \mathrm{O}$ caused a smaller increase in $\mathrm{PaO}_{2}$, the 


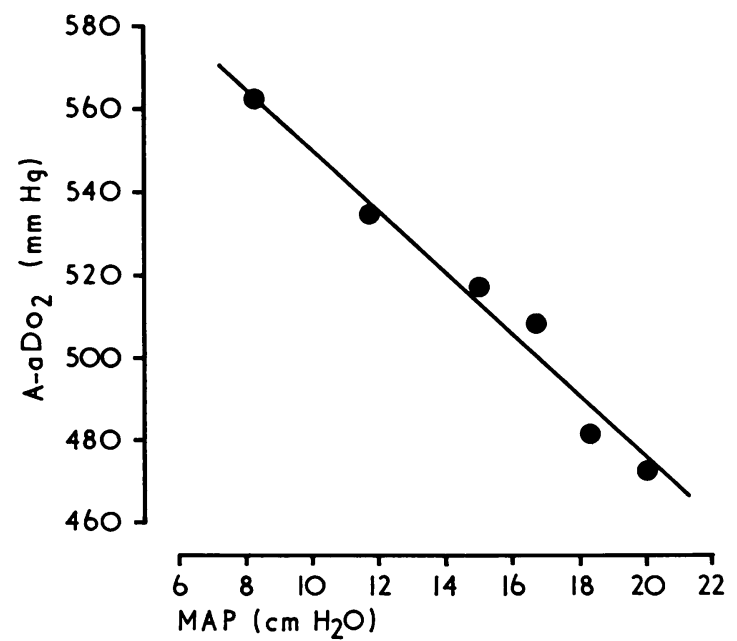

FIG. 3.-Relation between mean airway pressure (MAP) and alveolar-arterial oxygen difference $\left(A-a \mathrm{Do}_{2}\right)$.

effect of which was synergistic with that obtained from the long inspiratory phase, so that the highest $\mathrm{PaO}_{2}$ values found were with a 2:1 inspiration: expiration ratio and $5 \mathrm{~cm} \mathrm{H}_{2} \mathrm{O}$ of expiratory pressure (Fig. 2).

Calculation of the alveolar-arterial oxygen difference $\left(\mathrm{A}-\mathrm{aDO}_{2}\right)$ shows that the mechanism responsible for improving $\mathrm{PaO}_{2}$ when high inspiration:expiration ratios and positive expiratory pressures were employed was a reduction in rightto-left shunt. When high inspired oxygen concentrations are used, as in this study, the presence of an $\mathrm{A}-\mathrm{aDO} \mathrm{O}_{2}$ can be explained only by right-to-left shunting of blood (Rahn and Fenn, 1955): the demonstrated fall in $\mathrm{A}-\mathrm{aDo}_{2}$ therefore implies a reduction in shunt. It is possible to estimate the magnitude of this reduction by using a shunt nomogram (Nelson and Reynolds, 1964): at one extreme, with an inspiration:expiration ratio of $1: 2$ and no positive expiratory pressure (when $\mathrm{A}-\mathrm{aDo}{ }_{2}$ was maximal) the shunt amounted to about $53 \%$ of the cardiac output; at the other extreme, with a $2: 1$ inspiration:expiration ratio and $10 \mathrm{cmH}_{2} \mathrm{O}$ of expiratory pressure (when $\mathrm{A}-\mathrm{aDo}_{2}$ was minimal) it was approximately $33 \%$. No information is available from this study about the site at which right-to-left shunt was diminished. Improved alveolar inflation might, however, be expected to decrease intrapulmonary shunting of blood (Gregory et al., 1971), and also, by reducing pulmonary vascular resistance (Cassin et al., 1964), decrease extrapulmonary shunting through the foramen ovale and ductus arteriosus. Strong support for the view that improved alveolar inflation was the factor responsible for reducing $\mathrm{A}-\mathrm{aDo}_{2}$ and, therefore right-to-left shunt, comes from the finding of a very close correlation between mean airway pressure and $\mathrm{A}-\mathrm{aDo}_{2}$ (Fig. 3).

While the use of a high inspiration: expiration ratio and a positive expiratory pressure were both effective in reducing $\mathrm{A}-\mathrm{aDO}_{2}$ and right-to-left shunt, positive expiratory pressures suffered from the disadvantage, not present when the high inspiration: expiration ratio was employed, of causing alveolar hypoventilation (Fig. 2). The increase in $\mathrm{PaCO}_{2}$ with $5 \mathrm{~cm} \mathrm{H}_{2} \mathrm{O}$ of expiratory pressure was not very great, but with $10 \mathrm{~cm} \mathrm{H}_{2} \mathrm{O}, \mathrm{PaCO}_{2}$ was unacceptably high. Furthermore, failure to improve $\mathrm{PaO}_{2}$ when expiratory pressure was increased from $5 \mathrm{~cm} \mathrm{H}_{2} \mathrm{O}$ to $10 \mathrm{~cm} \mathrm{H}_{2} \mathrm{O} \mathrm{can}$, in the presence of a falling $\mathrm{A}-\mathrm{aDo}_{2}$, be attributed only to alveolar hypoventilation. Hypoventilation, therefore, limited the increase in $\mathrm{PaO}_{2}$ caused by reduction in right-to-left shunt. The probable reason for the occurrence of alveolar hypoventilation at high expiratory pressures is illustrated diagrammatically in Fig. 4, which shows an average static pressure-volume curve for infants dying from hyaline membrane disease derived from two published series (Gribetz, Frank, and Avery, 1959; Reynolds, Roberton, and Wigglesworth, 1968). Two tidal volumes are indicated on the deflation curve, one $\left(\mathrm{V}_{\mathrm{T}} \mathrm{l}\right)$ with pressures varying between $5 \mathrm{~cm} \mathrm{H}_{2} \mathrm{O}$ and $25 \mathrm{~cm} \mathrm{H}_{2} \mathrm{O}$, and the other $\left(\mathrm{V}_{\mathrm{T}} 2\right)$ between $10 \mathrm{~cm} \mathrm{H}_{2} \mathrm{O}$ and $25 \mathrm{~cm} \mathrm{H}_{2} \mathrm{O}$. It seems clear that as pressure during expiration

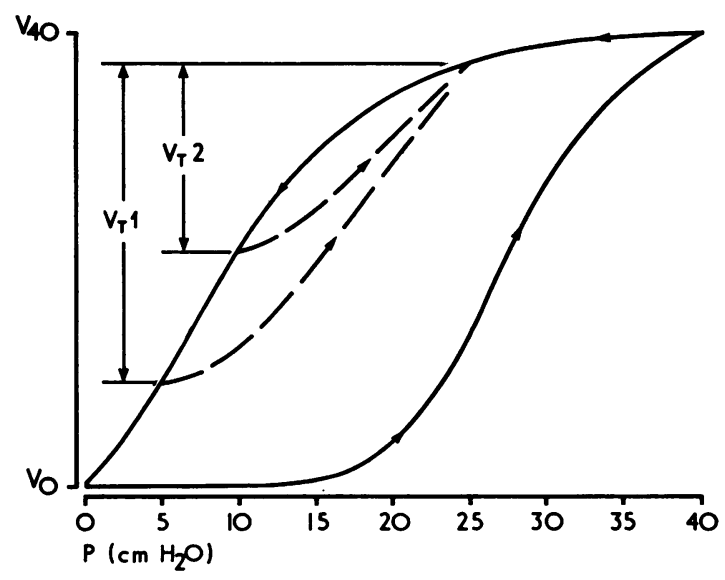

FIG. 4.-Mean static pressure volume curve of infants dying from hyaline membrane disease. Two schematic pressure $(P)$-tidal volume $\left(V_{T}\right)$ relations are shown to illustrate the probable effect of increasing positive pressure in expiration. $\quad V_{0}$ and $V_{40}=$ volume of gas present in the lung at transpulmonary pressures of 0 and $40 \mathrm{~cm} \mathrm{H}_{2} \mathrm{O}$. 
increases, tidal volume and minute volume will fall and $\mathrm{PaCO}_{2}$ will increase, so long as the other variables of ventilation, particularly peak airway pressure and respiratory frequency, remain constant.

Circulation. In a subject with normal lungs the use of high inspiration:expiration ratios and positive pressures in expiration would almost certainly cause a sufficient increase in mean intrathoracic pressure to embarrass the circulation, causing a fall in cardiac output and arterial blood pressure (Cournand et al., 1948; Morgan et al., 1966). In this study, however, as in others where infants with hyaline membrane disease have been treated with high airway pressures during spontaneous breathing (Gregory et al., 1971) or during mechanical ventilation (Reynolds, 1971), no alterations in aortic blood pressure were seen; neither was there clinical evidence of peripheral vasoconstriction, or any fall in base excess which would indicate the development of a metabolic acidaemia due to poor tissue perfusion. Measurement of intra-oesophageal pressure in two infants showed almost no transmission of pressure to the intrapleural space. The main reason for these findings is probably that high mean airway pressures are opposed by similar pressures developed in the alveoli due to the abnormal retractile force of the surfactant-deficient air liquid interfaces. Alveolar volume is therefore limited, and transmission of pressure to the intrapleural space is minimized. Under these circumstances it appears that high mean airway pressures can be used during the acute stage of severe hyaline membrane disease with little risk of causing adverse circulatory effects.

Implications for the ventilator management of hyaline membrane disease. As a result of this investigation we have added the use of a positive expiratory pressure to our previously defined regimen for ventilating infants with hyaline membrane disease (Reynolds, 1971). Not only does this manoeuvre have a useful effect in acutely reducing right-to-left shunt, as shown here, but it is also possible that steps taken to prevent alveolar collapse during expiration may prevent the development of progressively severe atelectasis (Gregory $e t$ al., 1971).

We start mechanical ventilation at a peak airway pressure of $25 \mathrm{~cm} \mathrm{H}_{2} \mathrm{O}$, a positive expiratory pressure of $5 \mathrm{~cm} \mathrm{H}_{2} \mathrm{O}$, a respiratory frequency of $30 / \mathrm{min}$, and an inspiration:expiration ratio of $1: 1$. The ventilator is set to produce a pressure wave-form resembling a square wave as closely as possible in order to obtain maximal alveolar inflation early in inspiration. Until it is clear that the infant is properly oxygenated, an oxygen concentration in inspired gas of about $95 \%$ is used. In our experience these ventilator settings are usually effective in achieving satisfactory gas exchange, at least initially. After 15 to 30 minutes, arterial blood gas tensions and $p \mathrm{H}$ are measured. If the $\mathrm{PaCO}_{2}$ is too high, it can be brought down by a small increase in frequency (to about $36-40 \mathrm{~min}$ ), but this carries the risk of reducing $\mathrm{PaO}_{2}$ (Reynolds, 1971). If the $\mathrm{PaO}_{2}$ is low and needs to be increased, or we wish to reduce inspired oxygen concentration while maintaining $\mathrm{PaO}_{2}$ constant, we increase inspiration:expiration ratio to $2: 1$ or more, aiming with the help of this manoeuvre to reduce the inspired oxygen concentration to 60 to $70 \%$. If a satisfactory $\mathrm{PaO}_{2}$ cannot be obtained in this way, peak airway pressure is also raised (to 28 or 30 $\mathrm{cm} \mathrm{H}_{2} \mathrm{O}$ ), but we are reluctant to do this unless forced because it may cause a pneumothorax or trauma to the lung: furthermore, the use of high peak airway pressures in immature surfactantdeficient lambs has been shown to be associated with increased transfer of protein into the air spaces (Normand, Reynolds, and Strang, 1970). In extremely severely affected infants in whom an adequate $\mathrm{PaO}_{2}$ is not obtainable with the measures which have already been described, we accept the risk of a pneumothorax and try the effect of a further increase in peak airway pressure (to $32-35 \mathrm{~cm} \mathrm{H}_{2} \mathrm{O}$ ) combined with an increase in positive expiratory pressure (to about $10 \mathrm{~cm} \mathrm{H}_{2} \mathrm{O}$ ). A period of ventilation lasting an hour or two at these pressures and with a very high inspiration:expiration ratio seems sometimes to be capable of progressively opening collapsed alveoli and producing a substantial rise in $\mathrm{PaO}_{2}$, which is largely maintained on reducing the ventilating pressures to a safer level.

Once recovery has started on about the third or fourth day, transmission of high mean airway pressures to the circulation becomes probable, and inspiration:expiration ratio is reduced to $1: 1$ or less as soon as possible. The infant is then weaned from the ventilator using the technique of Gregory et al. (1971).

We are grateful to Professor L. B. Strang for his encouragement, to the nursing staff of the Neonatal Unit for their constant help, and to Mr. M. J. Bright for technical assistance.

\section{REFERENCES}

Adamson, T. M., Hawker, J. M., Reynolds, E. O. R., and Shaw, J. L. (1969). Hypoxemia during recovery from severe hyaline membrane disease. Pediatrics, 44, 168.

Avery, M. E., and Mead, J. (1959). Surface properties in relation to atelectasis and hyaline membrane disease. American fournal of Diseases of Children, 97, 517. 
Banerjee, C. K., Girling, D. J, and Wigglesworth, J. S. (1972) Pulmonary fibroplasia in newborn babies treated with oxygen and artificial ventilation. Archives of Disease in Childhood, 47, 509.

Cassin, S., Dawes, G. S., Mott, J. C., Ross, B. B., and Strang, L. B. (1964). The vascular resistance of the foetal and newly ventilated lung of the lamb. Fournal of Physiology, 171, 61.

Chernick, V., and Vidyasagar, D. (1972). Continuous negative chest wall pressure in hyaline membrane disease: one year experience. Pediatrics, 49, 753 .

Cournand, A., Motley, H. L., Werkö, L., and Richards, D. W. (1948). Physiological studies of the effects of intermitten positive pressure breathing on cardiac output in man. American fournal of Physiology, 152, 162.

Gregory, G. A., Kitterman, J. A., Phibbs, R. H., Tooley, W. H., and Hamilton, W. K. (1971). Treatment of the idiopathic respiratory-distress syndrome with continuous positive airway pressure. New England fournal of Medicine, 284, 1333.

Gribetz, I., Frank, N. R., and Avery, M. E. (1959). Static volumepressure relations of excised lungs of infants with hyaline membrane disease. Fournal of Clinical Investigation, 38, 2168.

Hawker, J. M., Reynolds, E. O. R., and Taghizadeh, A. (1967) Pulmonary surface tension and pathological changes in infants dying after respirator treatment for severe hyaline membrane disease. Lancet, 2, 75.

Llewellyn, M. A., and Swyer, P. R. (1970). Positive expiratory pressure during mechanical ventilation in the newborn. Program and Abstracts. American Pediatric Society Inc. and the Society for Pediatric Research, Atlantic City, 29 April-2 May, p. 224.

Morgan, B. C., Martin, W. E., Hornbein, T. F., Crawford, E. W., and Guntheroth, W. G. (1966). Haemodynamic effects of intermittent positive pressure respiration. Anesthesiology, 27, 584.

Mushin, W. W., Rendell-Baker, L., Thompson, P. W., and Mapleson, W. W. (1969). Automatic Ventilation of the Lungs, 2nd ed. Blackwell, Oxford and Edinburgh.

Nelson, N. M., and Reynolds, E. O. R. (1964). Hyperbaric oxygen in patients with venoarterial shunts. Theoretical implications. New England fournal of Medicine, 271, 497.
Normand, I. C. S., Reynolds, E. O. R., and Strang, L. B. (1970). Passage of macromolecules between alveolar and interstitial spaces in foetal and newly ventilated lungs of the lamb. Fournal of Physiology, 210, 151.

Northway, W. H., Jr., Rosan, R. C., and Porter, D. Y. (1967). Pulmonary disease following respirator therapy of hyalinemembrane disease: bronchopulmonary dysplasia. New England fournal of Medicine, 276, 357.

Rahn, H., and Fenn, W. O. (1955). A Graphical Analysis of the Respiratory Gas Exchange. American Physiological Society, Washington D.C.

Reynolds, E. O. R. (1970). Indications for mechanical ventilation in infants with hyaline membrane disease. Pediatrics, 46, 193.

Reynolds, E. O. R. (1971). Effects of alterations in mechanical ventilator settings on pulmonary gas exchange in hyaline membrane disease. Archives of Disease in Childhood, 46, 152.

Reynolds, E. O. R. (1973). Pressure wave form and ventilator settings for mechanical ventilation in very severe hyaline membrane disease. International Anesthesiology Clinics. (In the press.)

Reynolds, E. O. R., Roberton, N. R. C., and Wigglesworth, J. S. (1968). Hyaline membrane disease, respiratory distress, and surfactant deficiency. Pediatrics, 42, 758.

Riley, R. L., and Cournand, A. (1949). 'Ideal' alveolar air and the analysis of ventilation-perfusion relationships in the lungs. fournal of Applied Physiology, 1, 825.

Senterre, J., and Geubelle, F. (1970). Measurement of endoesophageal pressure in the newborn. Biology of the Neonate, $16,47$.

Swyer, P. R., MacMurray, S. B., Hardie, M. J., Bryan, M. H., O'Brien, M. J., Llewellyn, M. A., and Chance, G. W. (1973). New methods of treatment of respiratory failure in the respiratory distress syndrome. In Perinatal Medicine, p. 297. Ed. by H. Bossart, J. M. Cruz, A. Huber, L. S. Prud'hom, and J. Sistek. Hans Huber, Bern, Stuttgart, and Vienna.

Correspondence to Dr. E. O. R. Reynolds, Department of Paediatrics, University College Hospital, Huntley Street, London WC1E 6AU. 